\title{
97. 事務所ビルの電力消費に及ぼす照明の省エネルギーの効果と
}

\section{蓄電池点灯による負荷平準化}

\author{
中野 幸夫 浅利 真宏 占部 亘 \\ （財団法人 電力中央研究所）
}

\section{1. はじめに}

事務所ビルの省エネと負荷平準化は重要な課 題である。事務所ビルのエネルギー消費全体に 占める照明の割合は $25 \%$ 程度であるが、O A 機 器の普及に伴って室内の発熱負荷が増大し、冬 季においても冷房の必要な場合が出現している。 冷房時に空調機が処理すべき熱負荷のうち $20 \%$ 程度は照明であり、照明エネルギーの削減 は冷房エネルギーを減らすという視点からも重 要である。また、負荷平準化の視点からは、蓄 熱空調につぐ方策として、Hf 蛍光灯に蓄電装置 を付加した照明器具（蓄電照明）(図 1 ) の開発 が進められている。そこで本報では、モデル事 務所ビル（延べ床面積 3, $280 \mathrm{~m}^{2}$ 、東京）を設定 し、ビル全体の電力消費特性に及ぼす照明の省 エネの影響と蓄電照明の導入による負荷平準化 の可能性について計算機シミュレーションを行 っている。

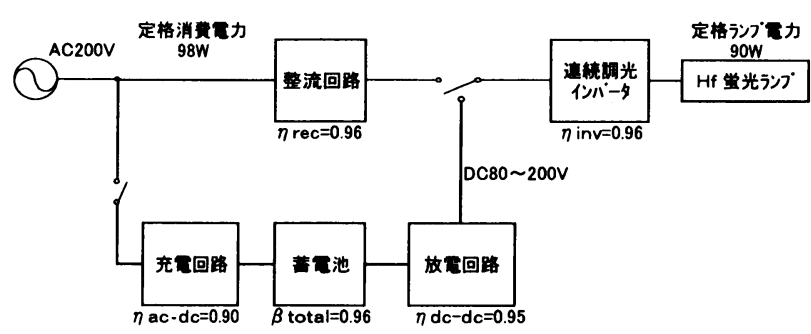

図 1 蓄電照明の構成図

\section{2. 評価ケース}

評価を実施したケースを表 1 に示す。ケース (1)〜(3)ではビル全体のエネルギー消費に及ぼす Hf 蛍光灯や調光機能による省エネの影響を、ま た、(4)および(5)では蓄電照明の負荷平準化量と 必要となる蓄電池容量を評価している。

\section{3. モデルビルの概要}

シミュレーションに用いたモデル事務所ビ
ルの概要を表 2 に示す。表 3 はビルの就業日の 運用パターンである。

表 1 評価ケース

\begin{tabular}{|c|c|c|}
\hline & $5-x$ & 事務室照明 \\
\hline \multirow{3}{*}{ 省エネルギー } & (1) & $\begin{array}{l}\text { 従来型蛍光灯 } \\
\text { (磁気回路式安定器形蛍光灯) } \\
\text { 定格 } 127 W / \text { 台 }\end{array}$ \\
\hline & (2) & $\begin{array}{l}\mathrm{Hf} \text { 蛍光灯（調光なし） } \\
\text { 定格 } 98 \mathrm{~W} / \text { 台 }\end{array}$ \\
\hline & (3) & Hf 虽光灯 (調光あり) \\
\hline \multirow[t]{2}{*}{ 負荷平準化 } & (4) & 蓄電照明（調光なし） \\
\hline & (5) & 蓄電照明 (調光あり) \\
\hline
\end{tabular}

表 2 モデル事務所ビルの概要

\begin{tabular}{|c|c|c|c|c|}
\hline 階構成 & $\mathrm{B} 1, \mathrm{~F} 7, \mathrm{P} 1$ & \multirow{2}{*}{$\begin{array}{l}\text { 在室 } \\
\text { 人員 } \\
\end{array}$} & 運用値 & 0.1 人 $/ \mathrm{m}^{2}$ \\
\hline 延べ床面積 & $3,280 \mathrm{~m}^{2}$ & & 設計値 & 0.2 人 $/ \mathrm{m}^{2}$ \\
\hline $\begin{array}{l}\text { 基準階 } \\
\text { 床面積 }\end{array}$ & $456 \mathrm{~m}^{2}$ & \multicolumn{2}{|c|}{ 外気量 } & $20 \mathrm{~m}^{3} / \mathrm{h}$ 人 \\
\hline アスペクト比 & 1. 44 & \multirow{7}{*}{ 照明 } & \multirow{3}{*}{ 事務室 } & $25 \mathrm{~W} / \mathrm{m}^{2}$ \\
\hline 1 階床面積 & $427 \mathrm{~m}^{2}$ & & & $19 \mathrm{~W} / \mathrm{m}^{2}$ \\
\hline 軒高 & $26.4 \mathrm{~m}$ & & & [表 3] \\
\hline $\begin{array}{c}\text { 基淮階 } \\
\text { 事務室面積 }\end{array}$ & $333 m^{2}$ & & 共用廊下 & $15 \mathrm{~W} / \mathrm{m}^{2}$ \\
\hline $\begin{array}{c}1 \text { 階 } \\
\text { 事務室面積 }\end{array}$ & $250 m^{2}$ & & エントランスホール & $20 W / m^{2}$ \\
\hline \multirow{2}{*}{ 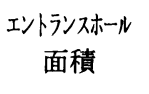 } & \multirow{2}{*}{$65 m^{2}$} & & 便所·湯沸 & $1.4 \mathrm{~kW}$ \\
\hline & & & 階段 & $1.4 \mathrm{~kW}$ \\
\hline $\begin{array}{c}\text { 基準階 } \\
\text { 廊下面積 }\end{array}$ & $41 \mathrm{~m}^{2}$ & \multirow{2}{*}{$\begin{array}{l}\text { コンセント } \\
\text { 負荷 }\end{array}$} & $\begin{array}{c}\text { 事務室 } \\
\text { (0A 機器) }\end{array}$ & $15 \mathrm{~W} / \mathrm{m}^{2}$ \\
\hline $\begin{array}{c}1 \text { 階 } \\
\text { 廊下面積 }\end{array}$ & $31 \mathrm{~m}^{2}$ & & 事務室以外 & $5 \mathrm{~W} / \mathrm{m}^{2}$ \\
\hline 空調 & マルチシスデム & & の他 & 全館禁煙 \\
\hline
\end{tabular}

表 3 在室率と照明・コンセントの 運用パターン（就業日）

\begin{tabular}{|c|c|c|c|c|c|c|c|}
\hline 時刻 & $0-8$ & $8-9$ & $9-12$ & $\begin{array}{r}12- \\
13\end{array}$ & $\begin{array}{r}13- \\
17\end{array}$ & $\begin{array}{r}17- \\
20\end{array}$ & $\begin{array}{c}20- \\
24\end{array}$ \\
\hline 在室率 & $0 \%$ & $10 \%$ & $75 \%$ & $30 \%$ & $75 \%$ & $30 \%$ & $0 \%$ \\
\hline $\begin{array}{c}\text { 照明 } \\
\text { 点灯率 }\end{array}$ & $0 \%$ & $50 \%$ & $100 \%$ & $70 \%$ & $100 \%$ & $50 \%$ & $0 \%$ \\
\hline $\begin{array}{c}\text { בンセে卜 } \\
\text { 負荷率 }\end{array}$ & $13 \%$ & $21 \%$ & $73 \%$ & $73 \%$ & $73 \%$ & $37 \%$ & $13 \%$ \\
\hline
\end{tabular}

Reduction in Electricity Consumption and Power Demand in Office Bui Iding with Energy Saving Luminaire Integrated with Storage Battery

NAKANO Yukio, et al. 
4. シミュレーション結果

動的熱負荷計算プログラム” HASP” に基づい たプログラムと東京の標準気象データを用いて 夏季と冬季の熱負荷ピーク日の熱負荷を計算し、 空調機器の仕様を決定し、ピーク電力需要を算 出した。その後、月代表日について熱負荷と消 費電力の 24 時間シミュレーションを行い、時刻 毎の消費電力量を算出した。ピーク電力需要と 年間消費電力量の計算結果を表 4 に示す。なお、 調光機能を有するケースの調光率は、標準気象 データに含まれる日射データとモンテカルロ法 を用いた照度計算プログラム（インテグラ社 製” INSPIRER”)を用いて計算している。また、 電力需要ピーク日について、蓄電照明 (439 台、 定格計 $42.7 \mathrm{~kW})$ を事務室の照明としてモデルビ ルに導入し、理想的な運用をした場合の電力日 負荷曲線の計算例を、導入前と比較して図 2 に 示す。図 3 は負荷平準化量に対する蓄電照明の 必要電池容量を示したものである。

表 4 モデル事務所ビルの電力消費特性

\begin{tabular}{|l|c|cc|}
\hline \multicolumn{1}{|c|}{ 照明 } & $\begin{array}{c}\text { ピーク電力需要 } \\
{[\mathrm{kW}]}\end{array}$ & $\begin{array}{c}\text { 年間消費電力量 } \\
{[\mathrm{MWh} / \text { 年] }}\end{array}$ \\
\hline 従来型蛍光灯 & $234(100 \%)$ & $486(100 \%)$ \\
\hline $\mathrm{Hf}$ 蛍光灯(調光なし) & $215(92 \%)$ & $444(91 \%)$ \\
\hline $\mathrm{Hf}$ 蛍光灯(調光あり) & $187(80 \%)$ & $395(81 \%)$ \\
\hline
\end{tabular}

\section{5. まとめ}

（1）ピーク電力需要に及ぼす影響（表 4)

照明の省エネ $1 \mathrm{~kW}$ がビル全体では約 $1.4 \mathrm{~kW} の$ ピーク電力需要の削减となる。

（2）年間消費電力量に及ほす影響（表 4)

照明の省エネ $1 \mathrm{kWh} /$ 年のがビル全体では 1.2 $\sim 1.3 \mathrm{kWh} /$ 年の省エネとなる。

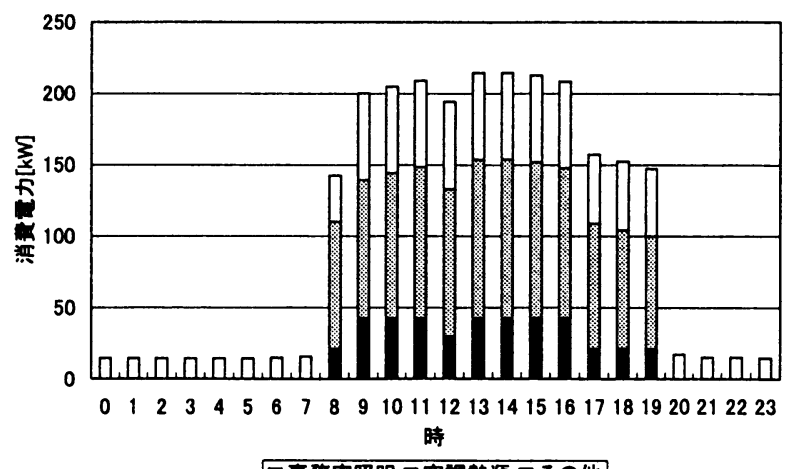

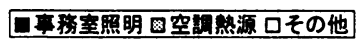

(a) Hf 蛍光灯（調光なし）
（3）蓄電照明による負荷平準化（図 2、図 3）

蓄電照明による負荷平淮化量は付加する蓄 電池の容量に依存するが、調光機能のない場合、 定格の上限 (42.7kW) まで負荷平準化をはかろ うとすると 953 Wh/台（ビル全体では $418 \mathrm{kWh）の}$ 蓄電池が必要となる。また、調光機能のある場 合には蓄電照明によって効果的に負荷平準化で きる上限は $22.1 \mathrm{~kW}$ であり、必要となる蓄電池の 容量は 442 Wh/台 (ビル全体では $194 \mathrm{kWh}$ ) となる。

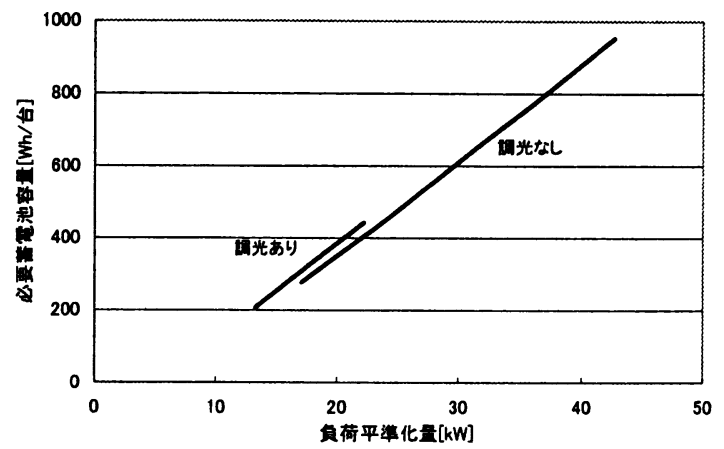

図 3 蓄電照明による負荷平準化量と 必要蓄電池容量

\section{謝辞}

本研究は、電力 8 社 (東北、中部、北陸、関西、中国、 四国、九州、沖縄) 他が実施する蓄電照明器具開発プロ ジェクトの一環として実施した。ご指導、ご鞭撻をたま わった関係各位に厚くお礼申し上げます。

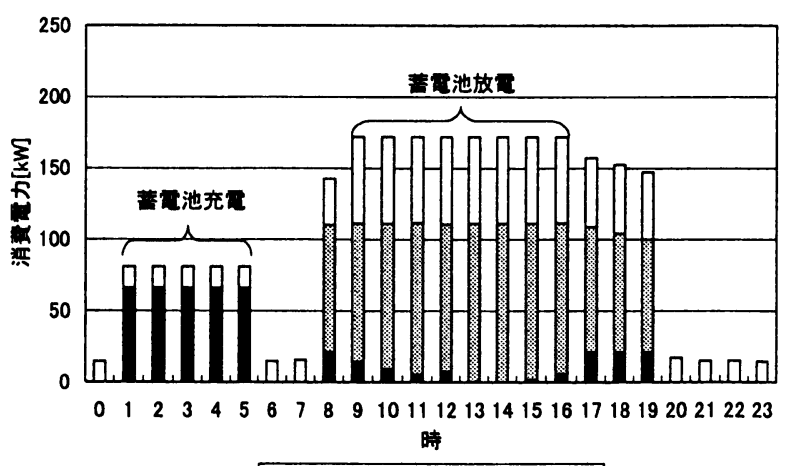

（b）蓄電照明（調光なし）

（負荷平準化量 42. 7kW、電池容量 953Wh/台）

図 2 蓄電照明による負荷平準化効果の例（電力需要ピーク日） 